American Journal of Pharmaceutical Education 2019; 83 (3) Article 6587.

\title{
RESEARCH
}

\section{Longitudinal Outcomes of an Elective Academic and Administrative Advanced Pharmacy Practice Experience}

\author{
Melissa S. Medina, EdD, ${ }^{\text {a }}$ Marcus Tad Autry, PharmD, ${ }^{\mathrm{a}}$ JoLaine R. Draugalis, PhD,,${ }^{\mathrm{a}, \mathrm{b}}$ \\ Stephen B. Neely, MPH, ${ }^{a}$ Mary R. Shreffler, PharmD, ${ }^{c}$ Sarah B. Hausner, PharmD ${ }^{d}$ \\ a The University of Oklahoma Health Sciences Center College of Pharmacy, Oklahoma City, Oklahoma \\ ${ }^{\mathrm{b}}$ Editorial Board Member, American Journal of Pharmaceutical Education, Arlington, Virginia \\ ${ }^{c}$ Texas Tech University Health Sciences Center School of Pharmacy, Amarillo, Texas \\ ${ }^{\mathrm{d}}$ VA North Texas Health Care System and Texas Tech University Health Sciences Center School of Pharmacy, Dallas, \\ Texas
}

Submitted June 14, 2017; accepted January 25, 2018; published April 2019.

Objective. To evaluate the impact of an academic and administrative advanced pharmacy practice experience (APPE) on participants' career choice and long-term retention of teaching knowledge.

Methods. Participants in an academic and administrative APPE from 2009 to 2016 completed a questionnaire about the experience and a 20-item knowledge test covering the five APPE modules. In addition, a retrospective review of graduates from the same timeframe was conducted to determine their faculty and preceptor status.

Results. Of the 17 APPE participants, 16 completed the study and 100\% reported that the experience helped them understand what it means to be a faculty member and an effective preceptor. The study participants completed the APPE knowledge test over the five modules. Participants passed four of the five module tests, including that for the instructional design module. A greater proportion of participants $(75 \%)$ obtained faculty positions than did graduates who had not completed the APPE (9\%). Seventy-one percent of students became active preceptors compared to $53 \%$ of students who did not complete the academic and administrative APPE, but this difference was not significant as the study was not powered to detect a difference.

Conclusion. A longitudinal analysis of an academic and administrative APPE found that $75 \%$ of participants pursued a faculty position and retained their knowledge over time. A majority of the APPE participants $(71 \%)$ and nonparticipants (53\%) obtained a preceptor license. The outcomes support continued offering of the academic and administrative APPE to fourth-year pharmacy (P4) students. Requiring all P4 students to complete the APPE could help make them "preceptor ready."

Keywords: teaching, instruction, faculty, training, standards

\section{INTRODUCTION}

Outcome 3.2 of the CAPE 2013 Educational Outcomes and Standard 3 of the 2016 Accreditation Council for Pharmacy Education Standards require schools and colleges of pharmacy to develop students as educators who can demonstrate effective teaching skills including preparing relevant content, selecting appropriate teaching methods, tailoring instruction, and assessing learning. ${ }^{1,2}$ Although the main purpose of these guidelines may be for

Corresponding Author: Melissa S. Medina, Department of Pharmacy: Clinical and Administrative Sciences, The University of Oklahoma College of Pharmacy, PO Box 26901, 1110 N. Stonewall, CPB 125, Oklahoma City, OK 73190. Tel: 405-271-6484. Fax: 405-271-3830. E-mail: melissa-medina@, ouhsc.edu pharmacy students to learn to educate patients, additional intended audiences are peers and other health care professionals. The educator subdomain was included in CAPE 2013 to highlight the importance of training students how to teach patients rather than present to patients. $^{1,3}$ Teaching is patient-centered and includes adapting content and assessing understanding. Presenting content is pharmacist-centered and focuses on delivering scripted content within a required timeframe and assuming patient comprehension., ${ }^{3,4}$

Colleges and schools of pharmacy may address the educator outcome in the didactic curriculum by embedding it into laboratories and skills-based courses such as a pharmacy practice course, a clinical communication laboratory, or a senior capstone or seminar course. ${ }^{5,6}$ Some 


\section{American Journal of Pharmaceutical Education 2019; 83 (3) Article 6587.}

programs also may address the educator standard in the experiential curriculum by offering an academic and administrative advanced pharmacy practice experience (APPE). As previously described in the literature, it is offered as an elective APPE to students who are interested in academic and administrative careers. ${ }^{7-9}$ The academic and administrative APPE typically covers topics such as instructional design, the science of teaching and learning, curriculum development, and assessment and feedback strategies, all of which are included in the educator subdomain. ${ }^{9-20}$ The benefit of an APPE dedicated to the educator standard is that it allows higher-level evaluation and application of teaching skills, which may not be available elsewhere in the curriculum. Educators have suggested that academic and administrative APPEs should be reserved for residency training because there is no evidence in the literature that the APPE increases the pursuit of faculty positions. ${ }^{21}$ However, the metric of pharmacy graduates pursuing faculty positions should not be limited to full-time appointments and should include adjunct faculty appointments, as more students may become preceptors rather than full-time faculty members. ${ }^{22}$ As such, an academic and administrative APPE may help students become "preceptor ready," 22 thereby benefitting a potentially larger cohort of students.

Our study was designed to address elements of this debate about the long-term outcomes of academic and administrative APPEs, which is important because the number of these APPEs is growing. ${ }^{21,22}$ The study objectives were to evaluate participants' perceptions of the academic and administrative APPE and its impact on career choice, as well as long-term retention of their teaching knowledge related to the educator outcome; compare the number of APPE participants to nonparticipants who accepted a fulltime faculty position as a first job upon completion of postgraduate work (residency or graduate school); and compare the number of eligible participants to nonparticipants who became preceptors after graduation. We hypothesized that students who completed the academic and administrative APPE would perceive that the APPE would be beneficial to them in future faculty positions and that they would remember a majority of the teaching-related content. We also hypothesized that a significantly higher percentage of academic and administrative APPE participants would pursue a faculty position after graduation. If similar materials and activities are included in academic and administrative APPEs at other pharmacy schools and the students are similar to those who completed this APPE, then it would seem that the results of our study would be generalizable.

\section{METHODS}

Since 2009, the University of Oklahoma Health Sciences Center College of Pharmacy (OUHSC COP) has offered an elective, four-week academic and administrative APPE, co-precepted by the college's CEO dean and the associate dean for assessment and evaluation and teacher preparation and development, who also serves as the director of preparing future faculty for the campus. Fourthyear students with an interest in academic career paths are encouraged to enroll in the APPE, which is offered in the spring semester each year to two to four students. Prior to data collection, the study was granted exemption by the OUHSC Institutional Review Board. Responses were kept confidential and participants were informed that the results only would be reported in aggregate.

Students enrolled in the academic and administrative APPE from 2009-2015 completed five modules (Pharmacy Curricula, Academic Pharmacy, Instructional Design, Delivering Feedback, and Academic Administration), each of which included relevant content, activities, and assessments (Table 1). Seventeen academic and administrative APPE students from the years of 2009 to 2016 were invited via email in August 2016 to participate in the study and complete a questionnaire consisting of 24 Likert-type items and one open-ended question about the experience, nine demographic items, and a locally developed 20 -item test (Table 2) that aligned with the APPE's objectives.

To identify the first job of all pharmacy graduates who pursued postgraduate training and had or had not completed the academic and administrative APPE, we conducted a retrospective review of an OUHSC College of Pharmacy database from the years 2009 to 2013. Only these years were included because no students completed the APPE in 2014 and students from 2015 and 2016 were still in training at the time of the study.

To determine the percentage of pharmacy graduates from 2009 to 2015 who had served or were serving as preceptors, we conducted a search of the Oklahoma State Board of Pharmacy preceptor database and then compared the number of OUHSC COP alumni serving as preceptors who had completed the APPE to the number who had not. Two groups of alumni were excluded from the review: those who graduated in 2014 when the APPE was not offered, and those from the class of 2016 as they were not eligible for a preceptor's license until one year after graduation. The Oklahoma State Board of Pharmacy records were chosen because historically $70 \%$ of students stayed in Oklahoma after graduation (as determined by the college's annual career placement survey).

Descriptive statistics were used to summarize the findings from the survey. The instrument used a 5-point Likert scale to rate agreement with items. Results from this section were presented as (frequency) percent for individual items as well as by CAPE 2013 domain and subdomain. ${ }^{1}$ Percent correct scores were calculated for 
American Journal of Pharmaceutical Education 2019; 83 (3) Article 6587.

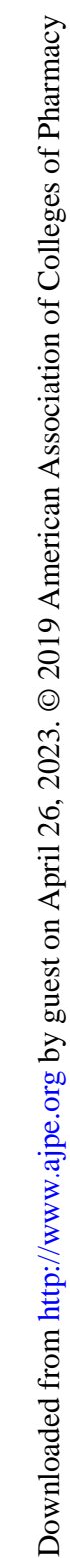

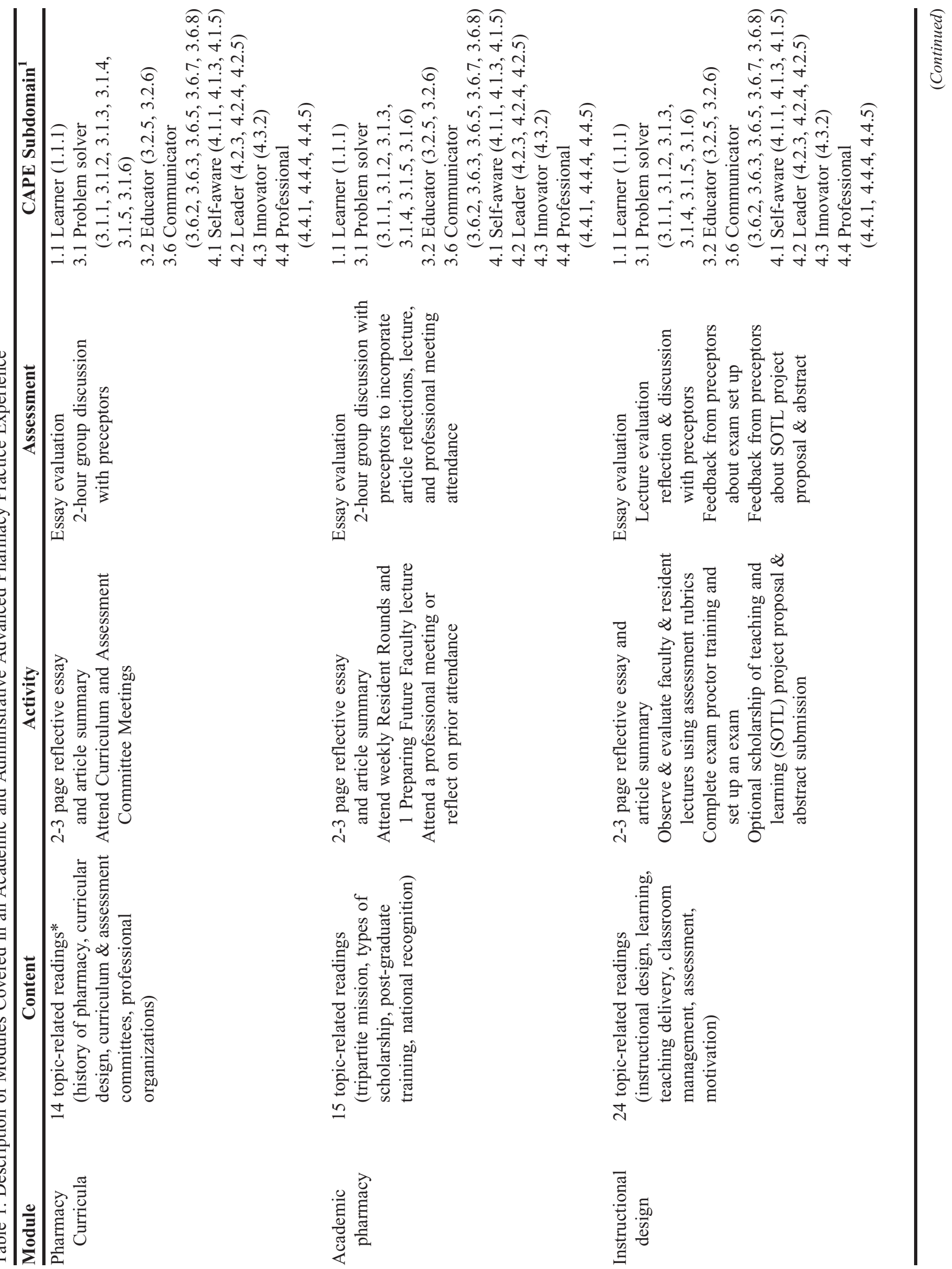


American Journal of Pharmaceutical Education 2019; 83 (3) Article 6587.

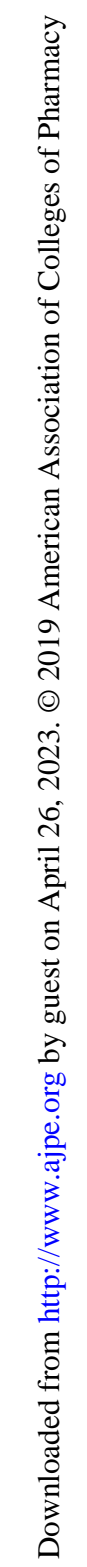

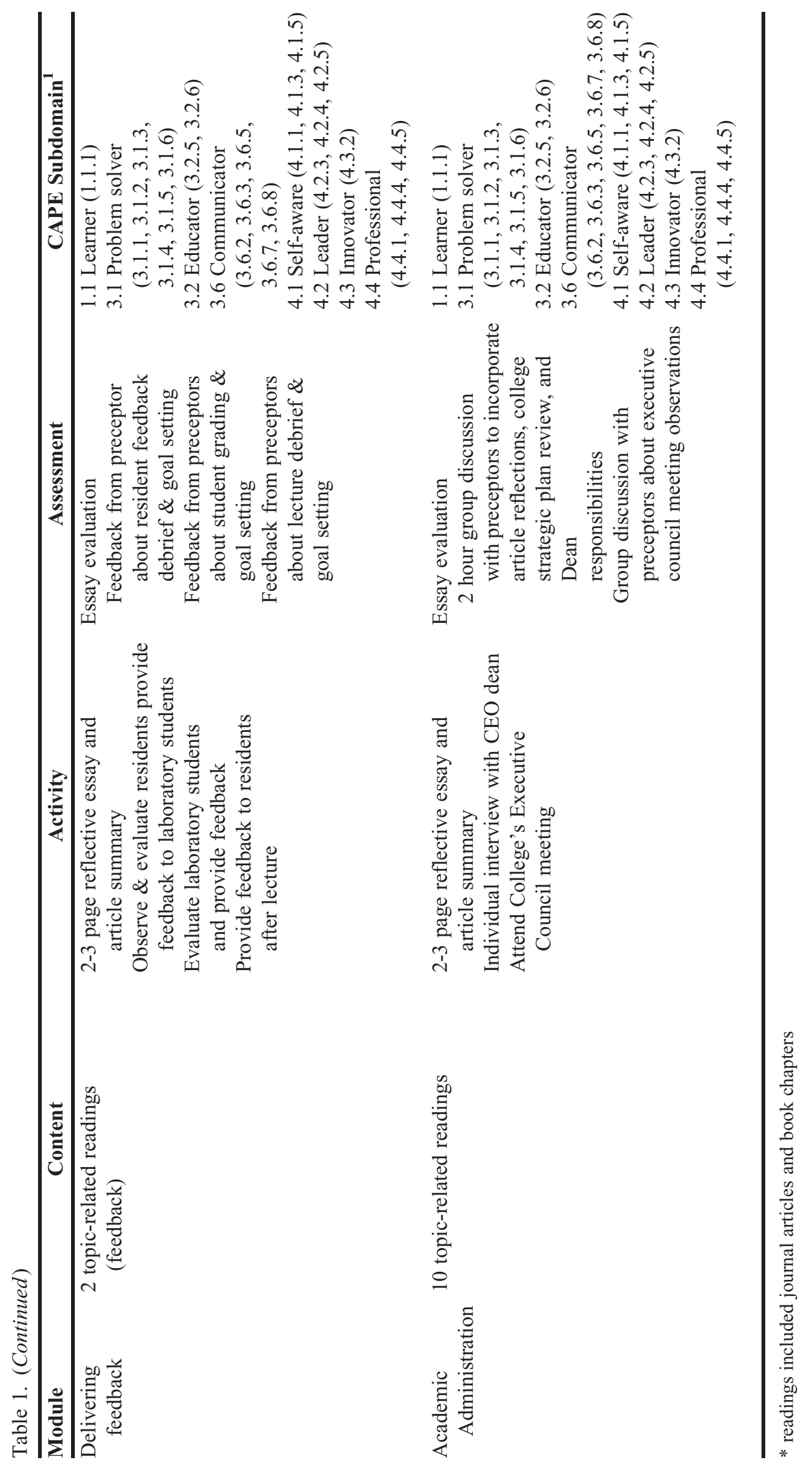




\section{American Journal of Pharmaceutical Education 2019; 83 (3) Article 6587.}

each question on the Teaching Knowledge and Skill Retention multiple-choice assessment. In addition to item analysis, questions were grouped by APPE modules to determine overall content area retention. Pearson $X^{2}$ and Fisher's Exact tests were used to determine differences between the percent of students on post-graduation statuses and academic and administrative APPE status. Each of these tests examined if the percent of academic and administrative APPE obtaining the post-graduation status was greater than nonparticipants. Results were summarized using frequency (percent). Statistical significance was set at $p<.05$. All analyses were conducted using SAS software v9,4 (SAS Institute, Cary, North Carolina).

\section{RESULTS}

Questionnaire results. Seventeen P4 students (five male and 12 female students) completed the academic and administrative APPE from 2009 to 2016. Sixteen of the 17 completed the survey questionnaire for a response rate of $94 \%$. Thirteen $(81 \%)$ participants pursued postgraduate training: $11(85 \%)$ entered a PGY1 residency and two entered $\mathrm{PhD}$ programs. Of the 13 , five were still completing their postgraduate training. Of the eight who had completed their postgraduate training, three became full-time faculty members and five began working as clinical pharmacists.

On questionnaire items related to career pursuits, $81 \%$ of the 16 respondents felt the APPE impacted their career path, 100\% indicated it helped them better understand what it means to be a faculty member, and $94 \%$ would recommend the APPE to current students regardless of what career they planned to pursue. Results related to preceptor knowledge revealed that the APPE helped 100\% understand how to be an effective preceptor, helped $100 \%$ develop better ways to deliver feedback, and encouraged 93\% to serve as a preceptor (Table 3).

Sixteen (94\%) of the 17 participants completed the APPE knowledge test of the five modules. All 16 respondents passed four of the five modules. Module mean percent correct scores were: pharmacy curricula, $72 \%$; pharmacy academia, 91\%; instructional design, 77\%; and feedback, $75 \%$. None of the participants passed the academic administration module (average score, 63\%; Table 2).

Post-graduation status results. Of the 604 graduates from 2009-2013 ten students completed the academic and administrative APPE. Review of institutional and college records found that a greater percentage of academic and administrative APPE students (80\%) entered residencies than those who had not taken the academic and administrative APPE $(13 \%), p<.001$. Of the graduates who completed residencies, a greater percentage obtained faculty appointments/positions if they had previously completed an academic and administrative APPE (75\%) than if they had not $(9 \%), p<.001$ (Table 4).

Preceptor status results. From 2009 to 2015 (excluding 2014) there were 708 OUHSC pharmacy graduates. From a search of the Oklahoma State Board of Pharmacy database, we confirmed preceptor status for $683(98 \%)$ alumni. Of the 708 graduates, 14 (2\%) completed the academic and administrative APPE. Ten (71\%) of the 14 APPE participants became active preceptors compared to 353 (53\%) of graduates who had not completed the APPE, however, this difference was not significant, $p=.13$, which may have been due to the low number of academic and administrative APPE students per year (Table 4).

\section{DISCUSSION}

The results from this study provide longitudinal data regarding academic and administrative APPEs. Similar to previous publications, the participants in this study agreed that the APPE impacted their career path and offered them a better understanding of faculty roles and responsibilities. Learning about an academic career path may demystify the expectations and help participants view it as an achievable goal. One limitation of our findings is that there may have been a selection bias as students interested in an academic career were also those most likely complete the academic and administrative APPE. In addition to pursuing an academic career, the study also found that the APPE participants retained core academic and administrative knowledge over time. This result suggests that the APPE participants will be able to apply their knowledge to future teaching encounters because they have remembered the content after several years.

There were two test items that participants scored poorly on: online testing and classroom management. This result was expected as online proctoring of examinations and classroom management strategies were not added to the APPE training until 2016. The finding also highlights two important areas for continuing professional development for faculty members. One limitation of this knowledge retention result is that the knowledge test only contained 20 items and 13 of the items were related to the teaching module specifically. The same results may not have been found if more test questions had been asked because a greater percentage of APPE content would have been covered. However, all the test questions that were developed were aligned with objectives that were associated with each APPE module.

Another significant finding was that a greater percentage of students who completed the academic and administrative APPE pursued postgraduate training upon graduation compared to their peers, which is important 


\section{American Journal of Pharmaceutical Education 2019; 83 (3) Article 6587.}

Table 2. Percent of Respondents Who Answered Correctly on Academic and Administrative APPE Teaching Knowledge and Skill Retention Multiple-Choice Questionnaire

\begin{tabular}{|c|c|c|}
\hline $\begin{array}{l}\text { Survey Question } \\
\text { Number }\end{array}$ & Survey Question & Percent Correct $(\mathrm{N}=16)$ \\
\hline Module 1 & Module 1 (Pharmacy Curricula) Mean Percent Correct & 72 \\
\hline Q1 & $\begin{array}{l}\text { Which organization is the national agency for the accreditation of } \\
\text { professional degree programs in pharmacy and providers of } \\
\text { continuing education? }\end{array}$ & 75 \\
\hline Q2 & $\begin{array}{l}\text { The Commission to Implement Change in Pharmaceutical Education } \\
\text { Background Papers were published in the: }\end{array}$ & 69 \\
\hline Module 2 & Module 2 (Academic Pharmacy) Mean Percent Correct & 91 \\
\hline Q3 & The tripartite mission refers to: & 100 \\
\hline Q4 & $\begin{array}{l}\text { Which one of the four types of scholarship defined by Ernest Boyer } \\
\text { reflects a research category that is still growing in acceptance by } \\
\text { university faculty as a legitimate research area }\end{array}$ & 81 \\
\hline Module 3 & Module 3 (Instructional Design) Mean Percent Correct ${ }^{23-27}$ & 77 \\
\hline Q5 & Identify the best verb from the list to use when writing an objective $e^{23,24}$ & 69 \\
\hline Q6 & $\begin{array}{l}\text { When distinguishing lower- and higher-level objectives, } \\
\text { higher level objectives } \operatorname{are}^{23} \text { : }\end{array}$ & 94 \\
\hline Q7 & To emphasize the message and text on your slide, the best strategy to use is ${ }^{24}$ : & 100 \\
\hline Q8 & $\begin{array}{l}\text { In the preview, view, review presentation format, one effective } \\
\text { strategy for reviewing content to }{ }^{24} \text { : }\end{array}$ & 88 \\
\hline Q9 & $\begin{array}{l}\text { During a teaching/lecture observation an important aspect of } \\
\text { active learning to evaluate is }{ }^{24} \text { : }\end{array}$ & 69 \\
\hline Q10 & $\begin{array}{l}\text { What is the best strategy for a presenter to use for future presentations } \\
\text { if he/she is not able to finish his/her lectures on time }{ }^{24} \text { ? }\end{array}$ & 88 \\
\hline Q11 & $\begin{array}{l}\text { When a student on rotation or in the classroom is exhibiting low intrinsic } \\
\text { and extrinsic motivation by not completing assignments what is } \\
\text { the best thing a faculty member should do? }\end{array}$ & 88 \\
\hline Q12 & $\begin{array}{l}\text { When a student is disrupting the class during a lecture, } \\
\text { the faculty member should: }{ }^{25}\end{array}$ & 44 \\
\hline Q13 & Identify the problem with the following question stem: "A Hemoglobin A1c:" & 88 \\
\hline Q14 & One of the best ways to evaluate a student's live performance of a skill is to: ${ }^{26}$ & 94 \\
\hline Q15 & $\begin{array}{l}\text { An assessment used during instruction to assess student } \\
\text { understanding is called: }\end{array}$ & 50 \\
\hline Q16 & The best strategy to use when setting up an exam is to: ${ }^{27}$ & 94 \\
\hline Q17 & $\begin{array}{l}\text { The best strategy to use when students are leaving a room after } \\
\text { completing an online test is for the students to: }{ }^{27}\end{array}$ & 44 \\
\hline Module 4 & Module 4 (Delivering Feedback) Mean Percent Correct $^{28}$ & 75 \\
\hline Q18 & The best strategy to use when providing feedback to students is to use the: ${ }^{28}$ & 63 \\
\hline Q19 & $\begin{array}{l}\text { When students are goal setting for future improvement } \\
\text { one of the biggest mistakes they make is: }{ }^{28}\end{array}$ & 88 \\
\hline Module 5 & Module 5 (Academic Administration) Mean Percent Correct & 63 \\
\hline Q20 & What is a CEO dean's primary responsibility at a national meeting? & 63 \\
\hline
\end{tabular}

*Note:* indicates references used for determining best answer to the given test question

as completion of postgraduate training is a requirement for obtaining most faculty positions. For those who pursued postgraduate training, significantly more academic and administrative APPE participants obtained full-time faculty positions compared to nonparticipants. This finding provides longitudinal data that were previously missing from the literature and offers support for continuing the availability of academic and administrative APPEs during the Doctor of Pharmacy program as a way to increase pursuit of a faculty position upon completion of postgraduate training. One limitation of this finding was that the academic and administrative APPE participants may have gotten the test questions correct and had more positive perceptions about teaching if they also completed postgraduate training that included a teaching certificate $\operatorname{program}(\mathrm{s})$. 


\section{American Journal of Pharmaceutical Education 2019; 83 (3) Article 6587.}

Table 3. Academic and Administrative APPE Participants' Perceptions of the Experience, Grouped by the CAPE Domains and Subdomains

\begin{tabular}{|c|c|c|c|c|c|c|c|}
\hline \multirow{2}{*}{$\begin{array}{l}\text { Survey } \\
\text { Question } \\
\text { Number }\end{array}$} & \multirow[b]{2}{*}{$\begin{array}{c}\text { CAPE } \\
\text { Standard }\end{array}$} & \multirow[b]{2}{*}{ Survey Question } & \multicolumn{5}{|c|}{ Likert Scale - Number (\%) Item $n=16$ unless noted } \\
\hline & & & $\begin{array}{c}\text { Strongly } \\
\text { Agree }\end{array}$ & $\begin{array}{c}\text { Somewhat } \\
\text { Agree }\end{array}$ & Neutral & $\begin{array}{c}\text { Somewhat } \\
\text { Disagree }\end{array}$ & $\begin{array}{l}\text { Strongly } \\
\text { Disagree }\end{array}$ \\
\hline Q61 & 1.1 & $\begin{array}{l}\text { The academic and administrative APPE helped } \\
\text { me to develop a better understanding of what } \\
\text { it means to be a faculty member. }\end{array}$ & $13(81)$ & $3(19)$ & $0(0)$ & $0(0)$ & $0(0)$ \\
\hline Q62 & 1.1 & $\begin{array}{l}\text { The academic and administrative APPE } \\
\text { helped me to develop a better } \\
\text { understanding of the roles and } \\
\text { responsibilities of a CEO dean. }\end{array}$ & $13(81)$ & $3(19)$ & $0(0)$ & $0(0)$ & $0(0)$ \\
\hline Q64 & 1.1 & $\begin{array}{l}\text { The academic and administrative APPE } \\
\text { helped me to develop a better } \\
\text { understanding of the rules, regulations, } \\
\text { and accreditation standards of an } \\
\text { institution of academic pharmacy. }\end{array}$ & $11(69)$ & $3(19)$ & $2(13)$ & $0(0)$ & $0(0)$ \\
\hline \multicolumn{3}{|c|}{ CAPE Standard 1 Overall } & 37 (77) & $9(19)$ & $2(4)$ & $0(0)$ & $0(0)$ \\
\hline Q18 & 3.2 & $\begin{array}{l}\text { The academic and administrative APPE } \\
\text { helped me to evaluate course objectives, } \\
\text { content, and lecture efficacy. }\end{array}$ & $9(56)$ & $6(38)$ & $1(6)$ & $0(0)$ & $0(0)$ \\
\hline Q19 & 3.2 & $\begin{array}{l}\text { The academic and administrative APPE } \\
\text { helped me to assess examination materials } \\
\text { - including test questions - for efficacy, } \\
\text { content, and structure. }\end{array}$ & $10(63)$ & $4(25)$ & $1(6)$ & $1(6)$ & $0(0)$ \\
\hline $\mathrm{Q} 30^{\mathrm{a}}$ & 3.2 & $\begin{array}{l}\text { The academic and administrative APPE } \\
\text { helped me to become a mentor } \\
\text { and/or preceptor. }\end{array}$ & $10(71)$ & $3(21)$ & $1(7)$ & $0(0)$ & $0(0)$ \\
\hline $\mathrm{Q} 32^{\mathrm{b}}$ & 3.2 & $\begin{array}{l}\text { The academic and administrative APPE } \\
\text { helped me become a more effective } \\
\text { preceptor. }\end{array}$ & $8(67)$ & $4(33)$ & $0(0)$ & $0(0)$ & $0(0)$ \\
\hline Q20 & 3.6 & $\begin{array}{l}\text { The academic and administrative APPE } \\
\text { helped me to develop effective means } \\
\text { to deliver feedback. }\end{array}$ & $13(81)$ & $3(19)$ & $0(0)$ & $0(0)$ & $0(0)$ \\
\hline Q21 & 3.6 & $\begin{array}{l}\text { The academic and administrative APPE } \\
\text { helped me to become a more assertive, } \\
\text { persuasive, confident, and clear } \\
\text { communicator. }\end{array}$ & $9(56)$ & $6(38)$ & $0(0)$ & $1(6)$ & $0(0)$ \\
\hline Q31 & 3.6 & $\begin{array}{l}\text { I currently use or have used the effective } \\
\text { feedback strategies taught to me during } \\
\text { the academic and administrative APPE } \\
\text { in my practice. }\end{array}$ & $12(75)$ & $4(25)$ & $0(0)$ & $0(0)$ & $0(0)$ \\
\hline \multicolumn{3}{|c|}{ CAPE Standard 3 Overall } & $71(67)$ & $30(28)$ & $3(3)$ & $2(2)$ & $0(0)$ \\
\hline Q22 & 4.1 & $\begin{array}{l}\text { The academic and administrative APPE } \\
\text { helped me become more self-aware } \\
\text { regarding my role and the roles of } \\
\text { faculty and administration within } \\
\text { academic pharmacy. }\end{array}$ & $12(75)$ & $4(25)$ & $0(0)$ & $0(0)$ & $0(0)$ \\
\hline Q23 & 4.1 & $\begin{array}{l}\text { The academic and administrative APPE } \\
\text { encouraged me to assess my career } \\
\text { plans and my goals for professional } \\
\text { development. }\end{array}$ & $11(69)$ & $4(25)$ & $1(6)$ & $0(0)$ & $0(0)$ \\
\hline
\end{tabular}


American Journal of Pharmaceutical Education 2019; 83 (3) Article 6587.

Table 3. (Continued)

\begin{tabular}{|c|c|c|c|c|c|c|c|}
\hline \multirow{2}{*}{$\begin{array}{l}\text { Survey } \\
\text { Question } \\
\text { Number }\end{array}$} & \multirow[b]{2}{*}{$\begin{array}{c}\text { CAPE } \\
\text { Standard }\end{array}$} & \multirow[b]{2}{*}{ Survey Question } & \multicolumn{5}{|c|}{ Likert Scale - Number (\%) Item $n=16$ unless noted } \\
\hline & & & $\begin{array}{c}\text { Strongly } \\
\text { Agree }\end{array}$ & $\begin{array}{l}\text { Somewhat } \\
\text { Agree }\end{array}$ & Neutral & $\begin{array}{c}\text { Somewhat } \\
\text { Disagree }\end{array}$ & $\begin{array}{l}\text { Strongly } \\
\text { Disagree }\end{array}$ \\
\hline Q24 & 4.2 & $\begin{array}{l}\text { The academic and administrative APPE } \\
\text { encouraged me to develop relationships } \\
\text { with faculty, administration, and other } \\
\text { APPE students. }\end{array}$ & $11(69)$ & $4(25)$ & $0(0)$ & $1(6)$ & $0(0)$ \\
\hline Q26 & 4.2 & $\begin{array}{l}\text { The academic and administrative APPE } \\
\text { encouraged me to work as a team with } \\
\text { faculty, administration, and other } \\
\text { APPE students. }\end{array}$ & $11(69)$ & $4(25)$ & $0(0)$ & $1(6)$ & $0(0)$ \\
\hline Q27 & 4.2 & $\begin{array}{l}\text { The academic and administrative APPE } \\
\text { empowered me as a student by providing } \\
\text { feedback, fostering collaboration, and } \\
\text { soliciting input. }\end{array}$ & $15(94)$ & $1(6)$ & $0(0)$ & $0(0)$ & $0(0)$ \\
\hline Q28 & 4.3 & $\begin{array}{l}\text { The academic and administrative APPE } \\
\text { encouraged me to develop new ideas } \\
\text { and ways of thinking regarding academic } \\
\text { pharmacy, education, mentorship, } \\
\text { professionalism, or the practice of } \\
\text { pharmacy. }\end{array}$ & $13(81)$ & $2(13)$ & $1(6)$ & $0(0)$ & $0(0)$ \\
\hline Q29 & 4.4 & $\begin{array}{l}\text { The academic and administrative APPE } \\
\text { helped me develop as a professional. }\end{array}$ & $15(94)$ & $1(6)$ & $0(0)$ & $0(0)$ & $0(0)$ \\
\hline \multicolumn{3}{|c|}{ CAPE Standard 4 Overall } & $88(79)$ & $20(18)$ & $2(2)$ & $2(2)$ & $0(0)$ \\
\hline $\mathrm{Q}^{3} 3^{\mathrm{a}}$ & N/A & $\begin{array}{l}\text { The academic and administrative APPE } \\
\text { encouraged me to pursue post-graduate } \\
\text { training, such as a residency. }\end{array}$ & $6(43)$ & $6(43)$ & $2(14)$ & $0(0)$ & $0(0)$ \\
\hline $\mathrm{Q} 34^{\mathrm{b}}$ & N/A & $\begin{array}{l}\text { The academic and administrative APPE } \\
\text { encouraged me to pursue a career in } \\
\text { academic pharmacy, such as a faculty } \\
\text { appointment in an institution of } \\
\text { pharmacy education. }\end{array}$ & $5(42)$ & $4(33)$ & $3(25)$ & $0(0)$ & $0(0)$ \\
\hline $\mathrm{Q} 35^{\mathrm{a}}$ & N/A & $\begin{array}{l}\text { The academic and administrative APPE } \\
\text { encouraged me to serve as a preceptor } \\
\text { for pharmacy students. }\end{array}$ & $9(64)$ & $4(29)$ & $0(0)$ & $1(7)$ & $0(0)$ \\
\hline Q36 & N/A & $\begin{array}{l}\text { Overall, I was satisfied with my academic } \\
\text { and administrative APPE experience. }\end{array}$ & $16(100)$ & $0(0)$ & $0(0)$ & $0(0)$ & $0(0)$ \\
\hline Q37 & N/A & $\begin{array}{l}\text { I would recommend this APPE to current } \\
\text { pharmacy students, regardless of } \\
\text { interest in pharmacy academy or } \\
\text { post-graduate training. }\end{array}$ & $13(81)$ & $2(13)$ & $0(0)$ & $1(6)$ & $0(0)$ \\
\hline Q38 & N/A & $\begin{array}{l}\text { The academic and administrative APPE } \\
\text { impacted my career path. }\end{array}$ & $9(56)$ & $4(25)$ & 3 (19) & $0(0)$ & $0(0)$ \\
\hline Q39 & N/A & $\begin{array}{l}\text { I feel as if the academic and } \\
\text { administrative APPE contributed } \\
\text { to making me a better professional. }\end{array}$ & $14(88)$ & $2(13)$ & $0(0)$ & $0(0)$ & $0(0)$ \\
\hline
\end{tabular}




\section{American Journal of Pharmaceutical Education 2019; 83 (3) Article 6587.}

Table 4. Post-Graduation Statuses by Academic and Administrative APPE Status

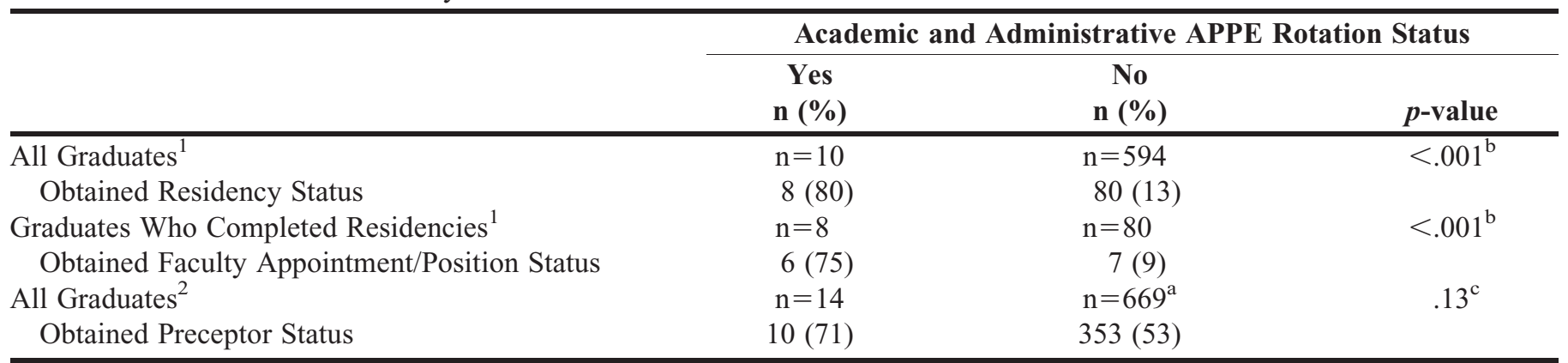

${ }^{1}$ For years 2009-2013. Excluded 2014 due to no academic and administrative APPE rotation and 2015-2016 due to graduates' still-in-training status at time of research

${ }^{2}$ For years 2009-2013 and 2015. Excluded 2014 due to no academic and administrative APPE rotation and 2016 due to graduates not yet eligible for preceptor status at time of research

${ }^{\text {a }}$ Preceptor status of 25 students unknown

${ }^{\mathrm{b}}$ Pearson $\mathrm{X}^{2}$ test

${ }^{\mathrm{c}}$ Fisher's Exact test

$\mathrm{APPE}=$ advanced pharmacy practice experience

The data also revealed that $71 \%$ of participants in the academic and administrative APPE and over $50 \%$ of nonparticipants obtained a preceptor's license, although it is not known if the nonparticipants were actively serving as preceptors. These findings support commentary by $\mathrm{Cox}^{22}$ advocating for graduates to be "preceptor ready." Completing an academic and administrative APPE can help students achieve this outcome. Preparing students for a future preceptor role can benefit colleges and schools of pharmacy that need effective preceptors to train their students. It can also help students learn how to become effective preceptors so they can better fulfill the role. Knowing that more than $50 \%$ of graduates become preceptors suggests that more students should complete an academic and administrative APPE to prepare them to serve in this important role.

The content covered in the five academic and administrative APPE modules supports teaching in the didactic or experiential settings, as evidenced by survey results from participants who agreed that the rotation helped encourage them to become a preceptor. The APPE also encouraged them to use effective strategies to deliver feedback, which is a frequently used preceptor skill.

Offering academic and administrative APPE content to an entire class of students through an APPE may be logistically difficult. An alternative solution may be to deliver the APPE content in a senior level capstone course or through self-study coupled with feedback from and discussion with a preceptor during a required APPE. Offering the academic and administrative APPE content to all students is one way to achieve domain 4 (personal and professional development) of the CAPE 2013 outcomes and the educator subdomain in domain 3 (approach to practice and care).
The APPE is also a way to ensure that students establish a foundation of effective precepting skills.

\section{CONCLUSION}

Longitudinal analysis of an academic and administrative APPE found that a majority of participants were pursuing careers in academia upon postgraduate training of residencies and graduate $(\mathrm{PhD})$ programs and that the rotation helped them understand the roles and responsibilities of a faculty member. Participants retained the knowledge they gained from the APPE over time, suggesting that the content can be applied to future teaching encounters. The results also revealed that over half of all graduates (both APPE participants and nonparticipants) obtained preceptor licenses. This suggests that the academic and administrative APPE content should be offered to all senior level students in some format, whether as an APPE or as course work in a senior level capstone course to systematically prepare students to serve as preceptors in the future.

\section{REFERENCES}

1. Medina MS, Plaza C, Stowe C, et al. Center for the Advancement of Pharmacy Education 2013 educational outcomes. Am J Pharm Educ.2013;77(8):Article 162.

2. Accreditation Council of Pharmacy Education. Accreditation standards and key elements for the professional program in pharmacy leading to the doctor of pharmacy degree. https://www.acpe-accredit. org/pdf/Standards2016FINAL.pdf. Accessed February 2016.

3. Medina MS, Herring H. Teaching during residency: five steps to better lecturing skills. Am J Health-Syst Pharm. March 2011;68: 382-387.

4. Robinson ET. The pharmacist as educator: implications for practice and education. Am J Pharm Educ. 2004;68(3):Article 72. 5. Ference J, Medina MS. Letter to the Editor regarding P4 seminar course. Am J Pharm Educ. 2008;72(5):Article 122. 


\section{American Journal of Pharmaceutical Education 2019; 83 (3) Article 6587.}

6. Saseen JJ, Linnebur SA, Borgelt LM, et al. A pharmacotherapy capstone course to target student learning and programmatic curricular assessment. Am J Pharm Educ. 2017;81(3):Article 45. 7. Roche VF, Limpach AL. A collaborative and reflective academic advanced pharmacy practice experience. Am J Pharm Educ. 2011; 75(6): Article 120.

8. Sylvia LM. An advanced pharmacy practice experience in academia. Am J Pharm Educ. 2006;70(5):Article 97.

9. Draugalis JR, Carter JT, Jackson TR. Pharmaceutical education advanced pharmacy practice experience and graduate course: materials, methods, and outcomes. Am J Pharm Educ. 1999;63:382-388.

10. Steinert Y, Mann K, Centeno A, et al. A systematic review of faculty development initiatives designed to improve teaching effectiveness in medical education. Med Teach. 2006;28(6): 497-526.

11. Knight AM, Cole KA, Kern DE, Barker LR, Kolodner K, Wright SM. Long-term follow-up of a longitudinal faculty development program in teaching skills. J Gen Intern Med. 2005;20(8):721-725. 12. Medina MS, Tomasek JJ, Bowers-Pippin J. The use of mentors and partnerships in a preparing future faculty program at a health sciences center. Curr Pharm Teach Learn. 2015;7(2):145-150. 13. Bloom BS (Ed.), Engelhart MD, Furst EJ, et al. Taxonomy of educational objectives: Handbook I: Cognitive domain. New York: David McKay; 1956.

14. Gronlund NE. How to write and use instructional objectives: $7^{\text {th }}$ edition. Upper Saddle River, NJ: Prentice Hall; 2004:128.

15. Medina MS. Providing feedback to enhance pharmacy students' performance. Am J Health-Syst Pharm. 2007; 64:2542-2545.

16. Medina MS, Williams VN, Fentem LR. The development of an education grand rounds program at an academic health center. Int J. Med Educ. 2010;1:30-36.
17. Steinert Y, Mann K, Centeno A, et al. A systematic review of faculty development initiatives designed to improve teaching effectiveness in medical education. Med Teach. 2006;28:497-526. 18. Cole KA, Barker LR, Kolodner K, Williamson P, Wright SM, Kern DE. Faculty development in teaching skills: an intensive longitudinal model. Acad Med. 2004;79(5):469-480.

19. Wilkerson L, Irby DM. Strategies for improving teaching practices: a comprehensive approach to faculty development. Acad Med. 1998;73:387-396.

20. Banta TW. Can assessment for accountability complement assessment for improvement? Peer Rev. 2007;9 (2):9-12.

21. Svensson C. What should constitute an acceptable advanced pharmacy practice experience? Am J Pharm Educ. 2016;80(3): Article 37.

22. Cox C. Quantity vs quality in experiential education. $A m J$ Pharm Educ. 2016;80(3):Article 36.

23. Medina MS. Using the 3 E's (emphasis, expectations, and evaluation) to structure writing objectives for pharmacy practice experiences. Am J Health-Syst Pharm. 2010; 67:516-521.

24. Medina MS, Avant ND. Delivering an effective presentation. Am $J$ Health-Syst Pharm. 2015; 72(13):1019-1024.

25. Medina MS. Assessing students' motivation during advanced pharmacy practice experiences. Am J Health-Syst Pharm.

2011;68:2230-2235.

26. Medina MS. Using rubrics to assess student performance on rotation. Am J Health-Syst Pharm. 2008;65(16):1502-1506.

27. Medina MS, Castleberry AN. A review of exam proctoring strategies for computer-based and paper-based tests. Am J HealthSyst Pharm. 2016;73(5):274-277.

28. Medina MS. Providing feedback to enhance pharmacy students' performance. Am J Health-Syst Pharm.2007;64:2542-2545. 


\section{American Journal of Pharmaceutical Education 2019; 83 (3) Article 6587.}

Appendix 1. Questionnaire

Demographics

1. Graduation year:

2. Did you pursue post-graduate training?

a. If so, what kind and where?

3. Did the availability of a teaching certificate positively influence your program decision?

4. Please list your first job (title and location) upon graduation or completion of post-graduate training.

5. Please list your current position (if different than above):

6. Please list your current area of practice (retail, hospital, clinical, academia, administration, etc.) a. Title:

7. Have you ever pursued a faculty position at a college or university? If so, where?

8. Are you currently working as a faculty or administrative member at a college or university? If so, where?

9. Do you precept students for IPPE or APPE rotations? If so, where.

\section{Attitudinal Items}

Please rate questions 1-24 as: Strongly Disagree, Disagree, Neutral, Agree, or Strongly Agree

1. The academic and administrative APPE (AAA APPE) helped me to develop a better understanding of what it means to be a faculty member. (CAPE 1.1)

2. The AAA APPE helped me to develop a better understanding of the roles and responsibilities of a CEO dean. (CAPE 1.1)

3. The AAA APPE helped me to develop a better understanding of the rules, regulations, and accreditation standards of an institution of academic pharmacy. (CAPE 1.1)

4. The AAA APPE helped me to evaluate course objectives, content, and lecture efficacy. (CAPE 3.2)

5. The AAA APPE helped me to assess examination materials - including test questions - for efficacy, content, and structure (CAPE 3.2)

6. The AAA APPE helped me to develop effective means to deliver feedback. (CAPE 3.6)

7. The AAA APPE helped me to become a more assertive, persuasive, confident, and clear communicator. (CAPE 3.6)

8. The AAA APPE helped me become more self-aware regarding my role and the roles of faculty and administration within academic pharmacy. (CAPE 4.1)

9. The AAA APPE encouraged me to assess my career plans and my goals for professional development. (CAPE 4.1)

10. The AAA APPE encouraged me to develop relationships with faculty, administration, and other APPE students. (CAPE 4.2)

11. The AAA APPE encouraged me to work as a team with faculty, administration, and other APPE students. (CAPE 4.2)

12. The AAA APPE empowered me as a student by providing feedback, fostering collaboration, and soliciting input. (CAPE 4.2)

13. The AAA APPE encouraged me to develop new ideas and ways of thinking regarding academic pharmacy, education, mentorship, professionalism, or the practice of pharmacy. (CAPE 4.3)

14. The AAA APPE helped me develop as a professional. (CAPE 4.4)

15. The AAA APPE helped me to become a mentor and/or preceptor (CAPE 3.2).

16. I currently use or have used the effective feedback strategies taught to me during the AAA APPE in my practice (CAPE 3.6).

17. The AAA APPE helped me become a more effective preceptor (CAPE 3.2).

18. The AAA APPE encouraged me to pursue a residency.

19. The AAA APPE encouraged me to pursue a career in academic pharmacy, such as a faculty appointment in an institution of pharmacy education.

20. The AAA APPE encouraged me to serve as a preceptor for pharmacy students.

21. Overall, I was satisfied with my experience in the AAA APPE

22. I would recommend this APPE to current pharmacy students, regardless of interest in pharmacy academy or post-graduate training.

23. The AAA APPE impacted my career path.

24. I feel as if the AAA APPE contributed to making me a better professional.

25. Please provide any comments about the AAA APPE: 